\title{
Three new species of Dolichoiulus millipedes from the underground of Gran Canaria, with notes on the circumscription of the genus (Diplopoda, Julida, Julidae)
}

\author{
Henrik ENGHOFF \\ Natural History Museum of Denmark, University of Copenhagen, \\ Universitetsparken 15, DK-2100 Copenhagen OE, Denmark. \\ Email: henghoff@snm.ku.dk
}

\begin{abstract}
Dolichoiulus typhlocanaria sp. nov., D. oromii sp. nov. and D. longunguis sp. nov. are described from caves and the mesovoid shallow stratum (MSS) on Gran Canaria. The genus Anagaiulus Enghoff, 1992 is synonymized under Dolichoiulus Verhoeff, 1900, resulting in Dolichoiulus blancatypa (Enghoff, 1992) comb nov.
\end{abstract}

Key words. Millipede, Canary Islands, new species, cave, Gran Canaria.

Enghoff H. 2012. Three new species of Dolichoiulus millipedes from the underground of Gran Canaria, with notes on the circumscription of the genus (Diplopoda, Julida, Julidae). European Journal of Taxonomy 15: 1-12. http:// dx.doi.org/10.5852/ejt.2012.15

\section{Introduction}

The millipede genus Dolichoiulus Verhoeff, 1900 includes one of the largest among the many radiations of plants and animals on the Canary Islands (Fernández-Palacios 2011). Of the 56 species hitherto included in the genus, 46 are Canarian endemics (Enghoff 1992, 2011; Enghoff \& Báez 1993). Enghoff (1992) revised the genus and described 39 new species. Despite considerable collecting activity on the Canary Islands since 1992, no additional new species have been discovered until now.

Five Canarian Dolichoiulus species have been found in caves, three endemic species on Tenerife, one endemic species on El Hierro and the introduced D. typhlops Ceuca, 1973 on La Palma and El Hierro (Enghoff 1992, 2002). The three Teneriffan cave species are blind, like the introduced D. typhlops. In recent years, blind Dolichoiulus millipedes have been collected in several caves and MSS (mesovoid shallow stratum, Romero 2009) on Gran Canaria. This material includes three new species and is the subject of the present paper. One of the new species shows a character that necessitates a re-evaluation of the genus Anagaiulus Enghoff, 1992, a monotypic genus from Tenerife.

\section{Material and methods}

Specimens were collected in MSS with special pitfall traps designed for collecting in this habitat (see López \& Oromí 2010), whereas those captured in caves and mines which were found by visual exploration. All were preserved in $70 \%$ ethanol and were examined with a stereomicroscope. A few 
specimens were 'analysed', i.e., gnathochilarium, an antenna, and some midbody legs were temporarily mounted in glycerol and examined at high magnification in a compound microscope. Gonopods/vulvae of some specimens were similarly placed in temporary mounts. Specimens for scanning electron microscopy were transferred to $96 \%$ ethanol and then to acetone, air-dried, mounted on aluminium stubs, coated with platinum/palladium and studied in a JEOL JSM-6335F scanning electron microscope (ZMUC).

Terminology follows Enghoff (1992) except that the term 'ring' or 'body ring' is used instead of 'segment', and 'mesomerital process' instead of 'mesomerite'.

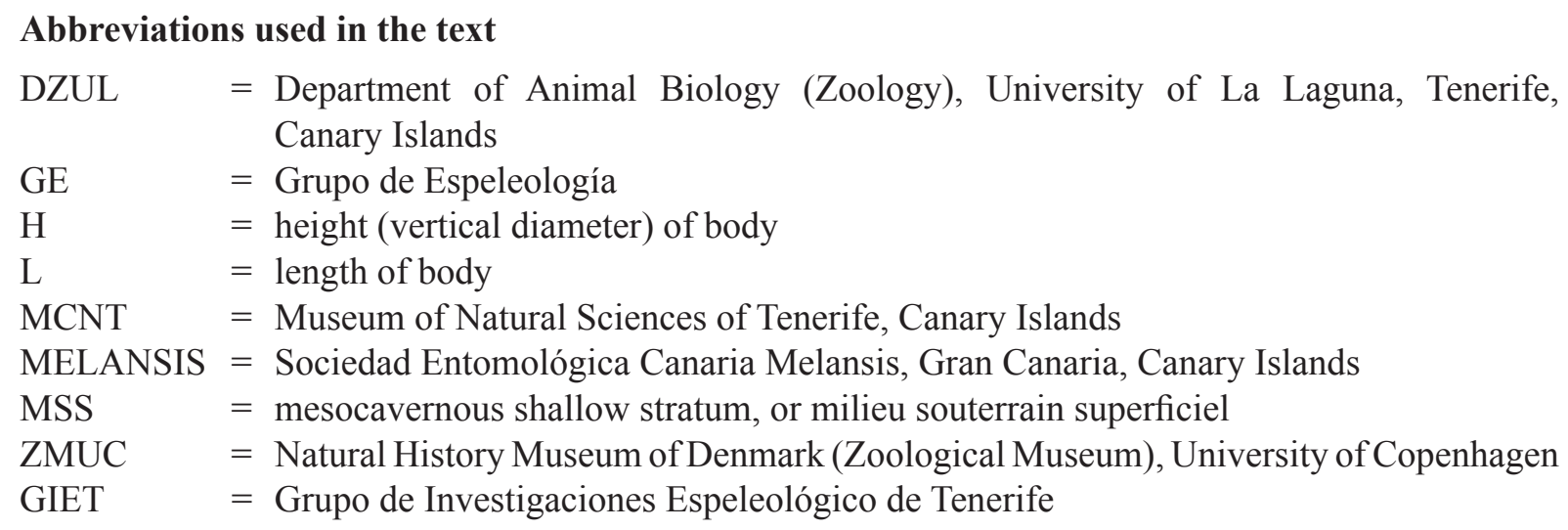

\title{
Results
}

\author{
Class Diplopoda Blainville-Gervais, 1844 \\ Order Julida Leach, 1814 \\ Family Julidae Leach, 1814 \\ Genus Dolichoiulus Verhoeff, 1900
}

Dolichoiulus Verhoeff, 1900: 85.

Nesopachyiulus Attems, 1902: 599, 607.

Trichopachyiulus Verhoeff, 1910: 194.

Anagaiulus Enghoff, 1992: 144 syn. nov.

See Enghoff (1992) for an in-depth discussion of Dolichoiulus. Anagaiulus was erected by Enghoff (1992) for a species which differs from the Dolichoiulus species in having a whorl of metazonital setae. Enghoff (1992) realized that this is a poor diagnostic character but preferred not to 'dilute' the already rather vague concept of Dolichoiulus by including a species with metazonital setae. Since then, two lines of evidence have emerged that contradict separate status for Anagaiulus:

1. One of the new species described in the present paper has metazonital setae; the other doesn't, but apart from this, and a size difference, the two species are as good as identical.

2. A preliminary molecular phylogenetic analysis by I. Sanmartín (unpublished) suggests that Anagaiulus is nested deeply inside Dolichoiulus.

\section{Diagnosis}

(from Enghoff 1992, emended): Pachyiulini. Eyes present or absent. No frontal setae. Mostly without metazonital setae (exceptions: D. blancatypa (Enghoff, 1992) comb. nov. and D. oromii sp. nov.). Metazonital striae mostly distinct also dorsally. No grooves in suture. No (or almost no) preanal projection. Preanal pilosity marginal or extensive. Anal valve pilosity extensive. Male mandibles mostly without lobes. First and second male legs typically julid. Male legs mostly with ventral pads. Anterior 
gonopod spoon-shaped, with a mesal ridge, a lateral prominence, and two apical denticles (which may be fused or reduced). Posterior gonopod without a sperm fovea, with a mesomerital process and with two opisthomerital processes, posterior process varying from short-triangular to flagelliform; one or both opisthomerital processes sometimes more or less reduced.

\section{Included species}

Dolichoiulus blancatypa (Enghoff, 1992), comb. nov. ex Anagaiulus, D. typhlocanaria sp. nov., D. oromii sp. nov., D. longunguis sp. nov., plus the 56 species included in Enghoff (1992).

Dolichoiulus typhlocanaria sp. nov.

Figs 1, 2A, 3A, B, 4A, B

\section{Diagnosis}

A blind species of Dolichoiulus. Differs from other blind Dolichoiulus species as shown in Table 1. Differs from the other blind Dolichoiulus on Gran Canaria in size (Figs 1, 5). Differs from D. oromii sp. nov. in lacking metazonital setae, in having only marginal preanal pilosity, and in having a terminal projection on the mesal ridge of the anterior gonopod. Differs from $D$. longunguis sp. nov. and the widespread D. typhlops in having clearly slenderer anterior gonopods (Fig. 3A, B, cf. Fig. 3D).

\section{Etymology}

The name (noun in apposition) refers to the blindness of this species from Gran Canaria.

\section{Type locality}

GRAN CANARIA (Canary Islands), Barranco del Draguillo.

Material examined (all from Canary Islands: Gran Canaria)

\section{Holotype}

§, Barranco del Draguillo, UTM 28R 4561/30913 (2756’45”N, 15²6’45”W), MSS, 26 Dec. 2006, H. López leg. (DZUL).

\section{Paratypes}

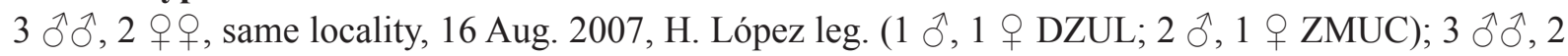

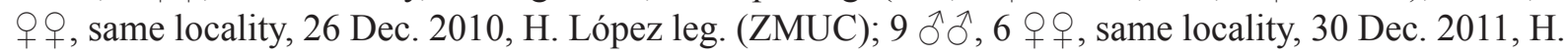
López leg. (DZUL).

\section{Referred (non-type) material}

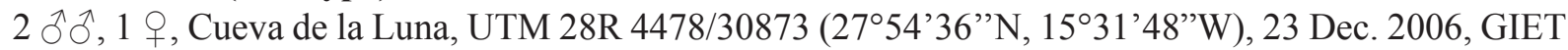

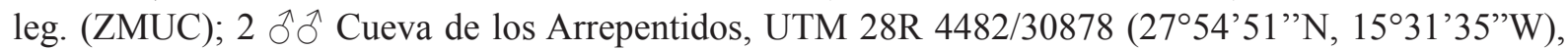
26 Dec. 2006, GIET leg. (DZUL); 1 ㄱ, 2 우, Los Majateles, UTM 28R 4505/30915 (2756’08”N, 15³0’10’W), MSS, 26 Dec. 2010, H. López leg. (DZUL).

\section{Total material}

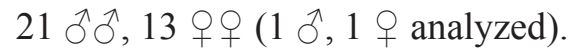

\section{Description}

స: L 14-20 mm, H 1.03-1.26 mm, L/H 13-16, 33-52 podous rings + 1-2(3?) apodous rings in front of telson.

q: L 15-20 mm, H 1.17-1.41 mm, L/H 12-16, 36-52 podous rings + 2 apodous rings in front of telson. 


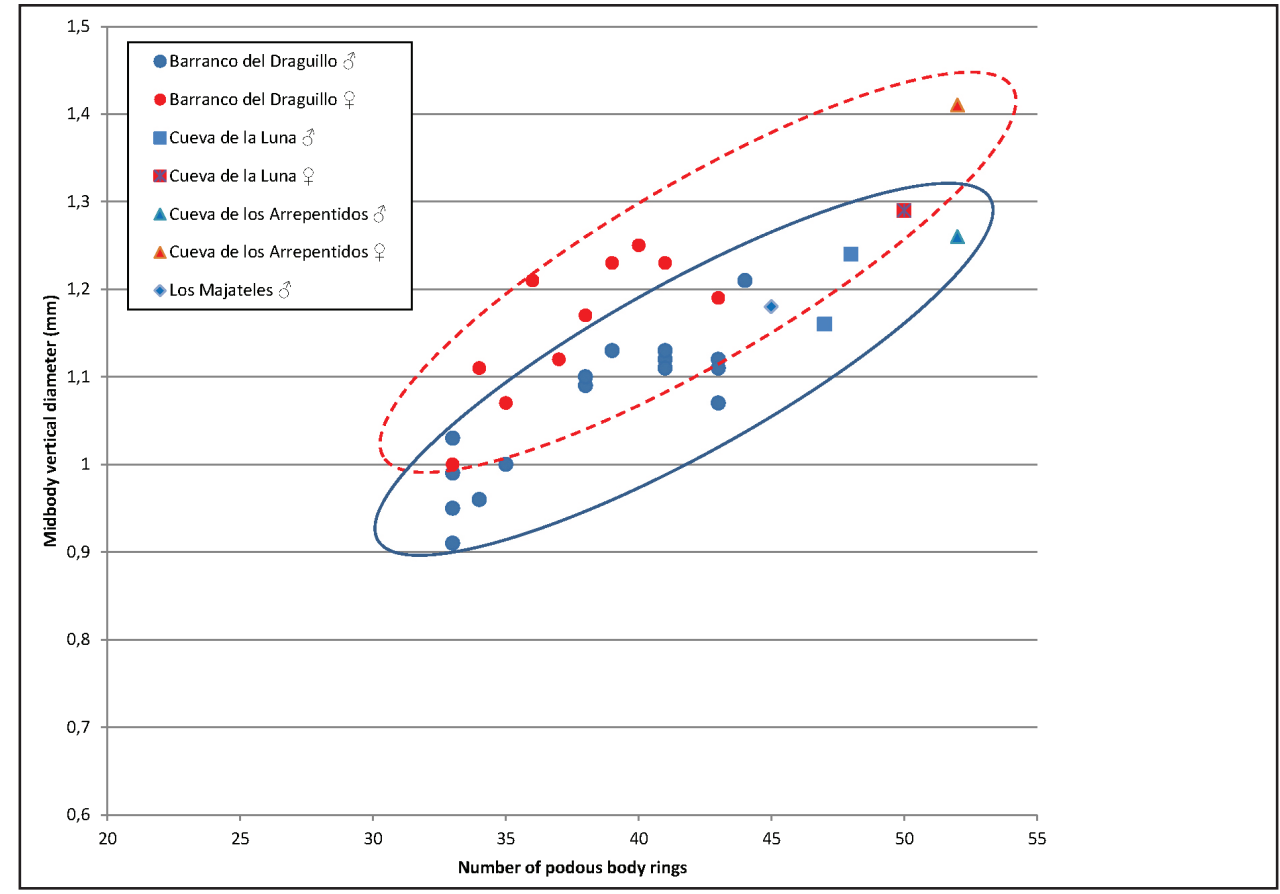

Fig. 1. Size diagram for Dolichoiulus typhlocanaria sp. nov. The diagram shows number of podous (leg-bearing) body rings (p.r., $\mathrm{x}$ axis) and vertical body diameter in $\mathrm{mm}$ (y axis). For a given number of podous rings $D$. typhlocanaria sp. nov. is thicker than the two other species (see Fig. 5), and females are thicker than males.
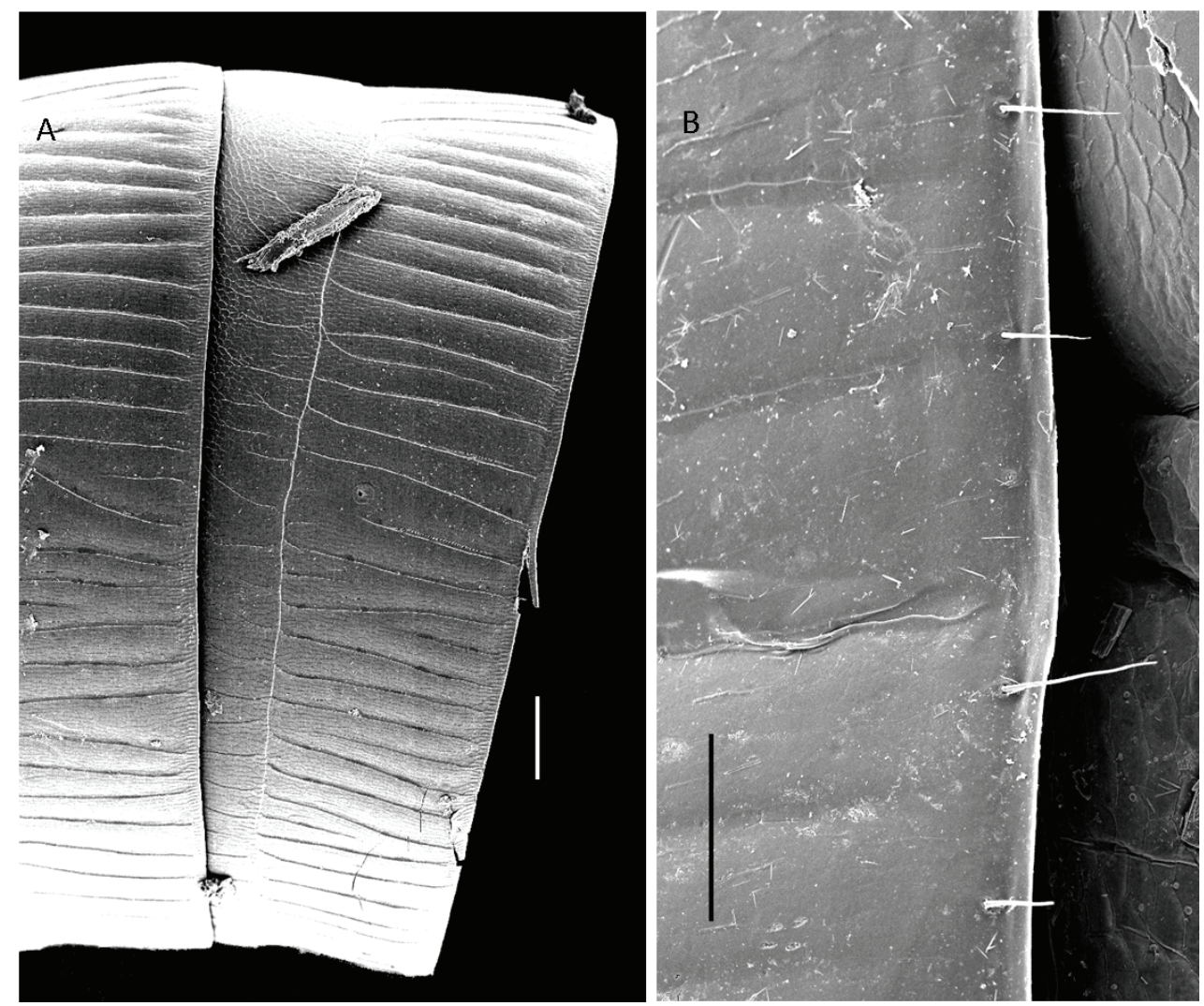

Fig. 2. A. D. typhlocanaria sp. nov., male from Cueva de la Luna, midbody rings. Scale $0.1 \mathrm{~mm}$. B. $D$. oromii sp. nov., detail of posterior margin of midbody ring, showing diagnostic setae. Scale $0.05 \mathrm{~mm}$. 
Colour. The preserved specimens are uniform whitish yellow. Defence glands in part visible by transparency as dark spots.

HEAD. No eyes. 4 supralabral setae. Setae on gnathochilarial stipes: 3 apical, 2-3 (ð) / 0 (†) nonapical. Length of antennae $156 \%$ of $\mathrm{H}$ in $\widehat{O}, 124 \%$ of $\mathrm{H}$ in 9 .

Body Rings. (Fig. 2A) Prozonites posteriorly furrowed, at least in specimens from Cueva de la Luna. Metazonites unvaulted, with $c .12$ striae per dorsal quarter. Ozopore $c .1 / 3$ metazonite length behind suture. Limbus cell length $c .4 \times$ width; their free margin with a few tiny denticles (as in Enghoff, 1992: figs 28-29).

Legs. Length $94 \%$ of $\mathrm{H}$ in ${ }^{\lambda}, 78 \%$ of $\mathrm{H}$ in + . Claw: length $6-8 \%$ of leg, length/height 3.4-5.2. Accessory claw $0.4 \times$ shorter than claw.

PREANAL RING. Without a projection, pilosity marginal.

\section{Male}

MANDibular STIPITES. Without lobes.

LEGS. Second pair with ventral pads on postfemur and tibia. Postfemoral pads tiny, tibial pads small on midbody legs. Second pair with coxal pores.

ANTERIOR GONOPODS. (Fig. 3A, B) Slender, basal shaft more than half as broad as distal bowl. Ridge with a terminal projection. Lateral prominence distinct. Bowl slender, rounded-triangular. Apical denticles distinct.

Posterior gonopods. (Fig. 4A, B) Mesomerital process almost as long as opisthomerite, straight. Opisthomerite slender, straight. Anterior process short, triangular, pointed. Posterior process longer, slender.

\section{Female}

ReCEPTACUlum SEMINIs. A stalked sphere (as in Enghoff 1992: fig. 48).

\section{Distribution and habitat}

Endemic to Gran Canaria. Known from two caves and three MSS in the east-central part of the island.

Dolichoiulus oromii sp. nov.

Figs 2B, 3C, 4C, 5

\section{Diagnosis}

A blind species of Dolichoiulus. Differs from other blind Dolichoiulus species as shown in Table 1. Differs from all other Dolichoiulus species, except D. blancatypa (Enghoff, 1992) comb. nov., in having metazonital setae. Differs further from the other blind Dolichoiulus on Gran Canaria in size (Figs 1, 5 ), in having extensive preanal pilosity, and in lacking a terminal projection on the mesal ridge of the anterior gonopod. Differs from $D$. longunguis sp. nov. and the widespread D. typhlops in having slenderer anterior gonopods (Fig. 3C, $c f$. Fig. 3D). Differs from D. blancatypa (from Tenerife) in having the mesomerital process clearly separated from the opisthomerite.

\section{Etymology}

The species in named in honour of Pedro Oromí, La Laguna, Tenerife, in recognition of his vast effort to document and analyse the Canarian fauna. 
European Journal of Taxonomy 15: 1-12 (2012)

\begin{tabular}{|c|c|c|c|c|c|c|c|c|}
\hline 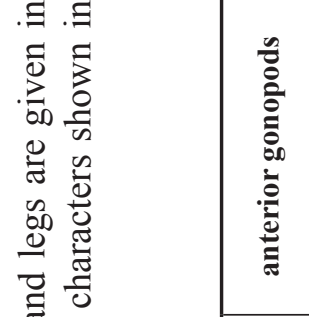 & 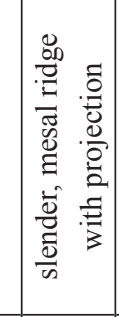 & 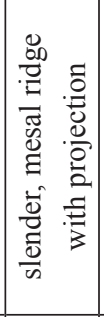 & 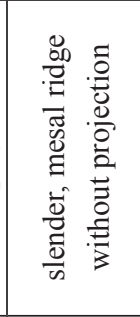 & 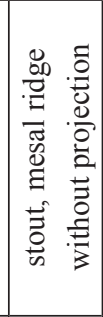 & 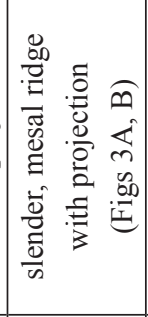 & 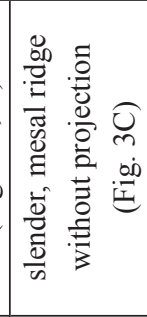 & 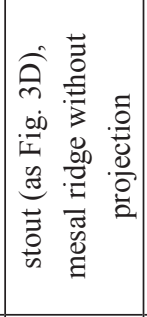 & 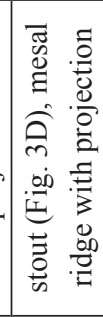 \\
\hline 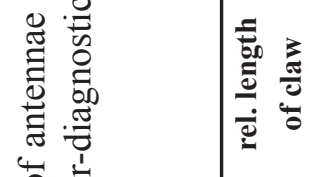 & 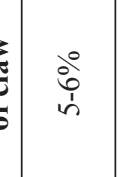 & $\begin{array}{l}\stackrel{0}{a} \\
\text { co }\end{array}$ & ڤे & $\stackrel{0}{=}$ & $\begin{array}{l}\stackrel{0}{0} \\
\dot{0} \\
\dot{b}\end{array}$ & $\begin{array}{l}\stackrel{0}{\infty} \\
i \\
i\end{array}$ & $\stackrel{\ominus}{\Rightarrow}$ & $\frac{\partial_{0}^{\circ}}{b}$ \\
\hline 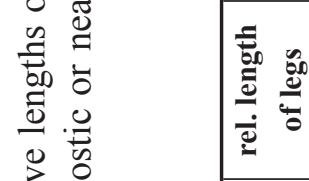 & 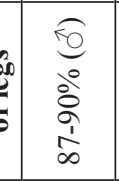 & 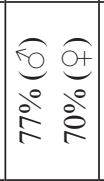 & : & 每 & 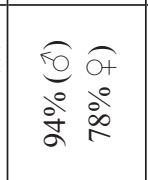 & 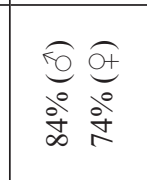 & 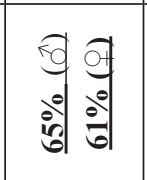 & 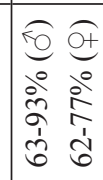 \\
\hline 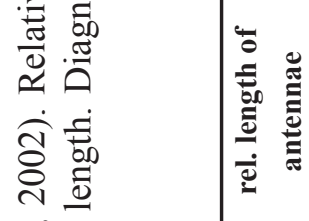 & 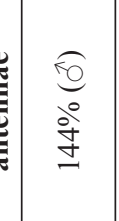 & 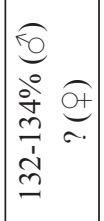 & 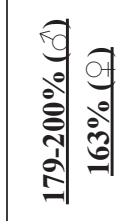 & 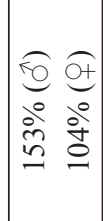 & 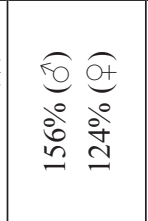 & 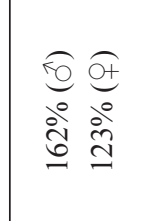 & 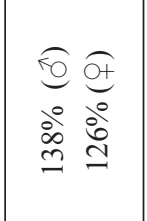 & 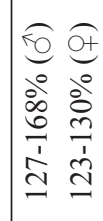 \\
\hline 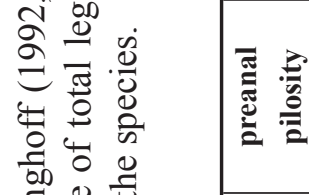 & 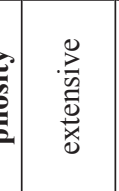 & 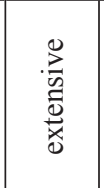 & 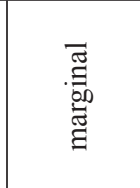 & 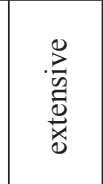 & 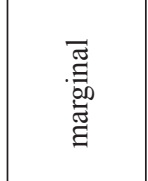 & 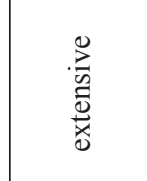 & 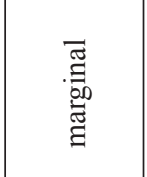 & $\begin{array}{l}\frac{0}{0} \\
\frac{\pi}{\pi} \\
\frac{\pi}{\nu}\end{array}$ \\
\hline 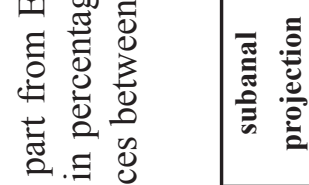 & $\stackrel{\mathscr{\Xi}}{g}$ & 㻤 & 䒓 & : & 号 & $\stackrel{\mathscr{\Xi}}{\Xi}$ & 号 & $\stackrel{\mathscr{\Xi}}{\Xi}$ \\
\hline 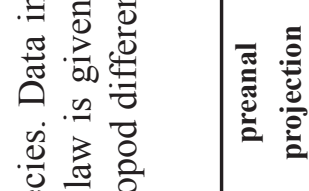 & 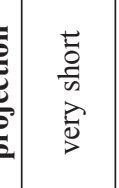 & 弟 & 蒿 & 芯 & : & $\stackrel{\mathscr{z}}{\tilde{z}}$ & 莺 & 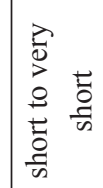 \\
\hline 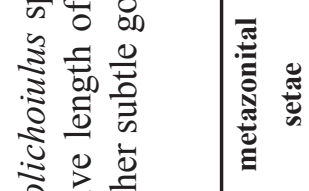 & 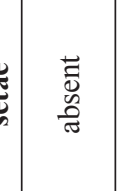 & 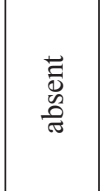 & $\begin{array}{l}\overrightarrow{\tilde{E}} \\
\text { 品 }\end{array}$ & 苛 & $\begin{array}{l}\overrightarrow{\tilde{D}^{\circ}} \\
\text { 岕 }\end{array}$ & 雚 & 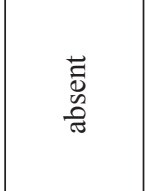 & $\begin{array}{l}\text { च. } \\
\text { d. } \\
\text { ते }\end{array}$ \\
\hline 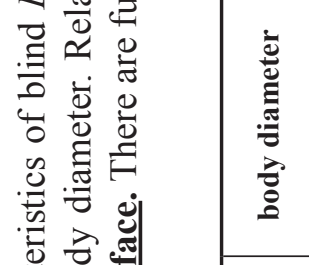 & 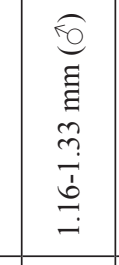 & 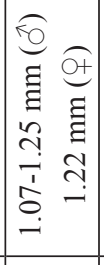 & 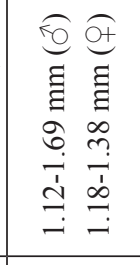 & 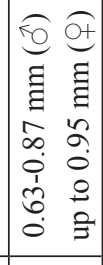 & 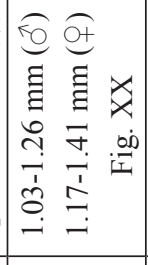 & 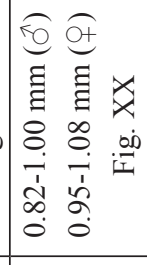 & 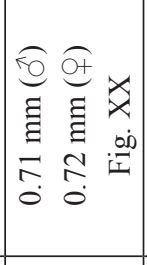 & 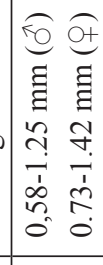 \\
\hline 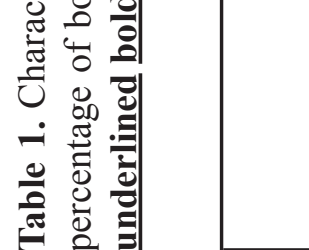 & 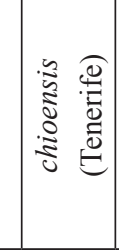 & 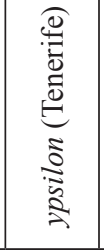 & 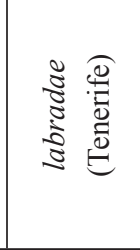 & 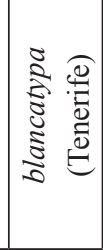 & 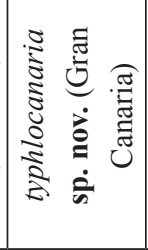 & 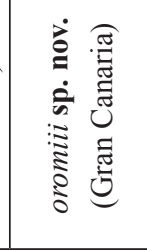 & 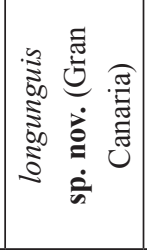 & 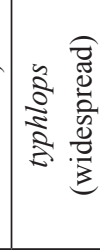 \\
\hline
\end{tabular}




\section{Type locality}

GRAN CANARIA (Canary Islands), El Sao.

\section{Material studied}

all from Canary Islands: Gran Canaria.
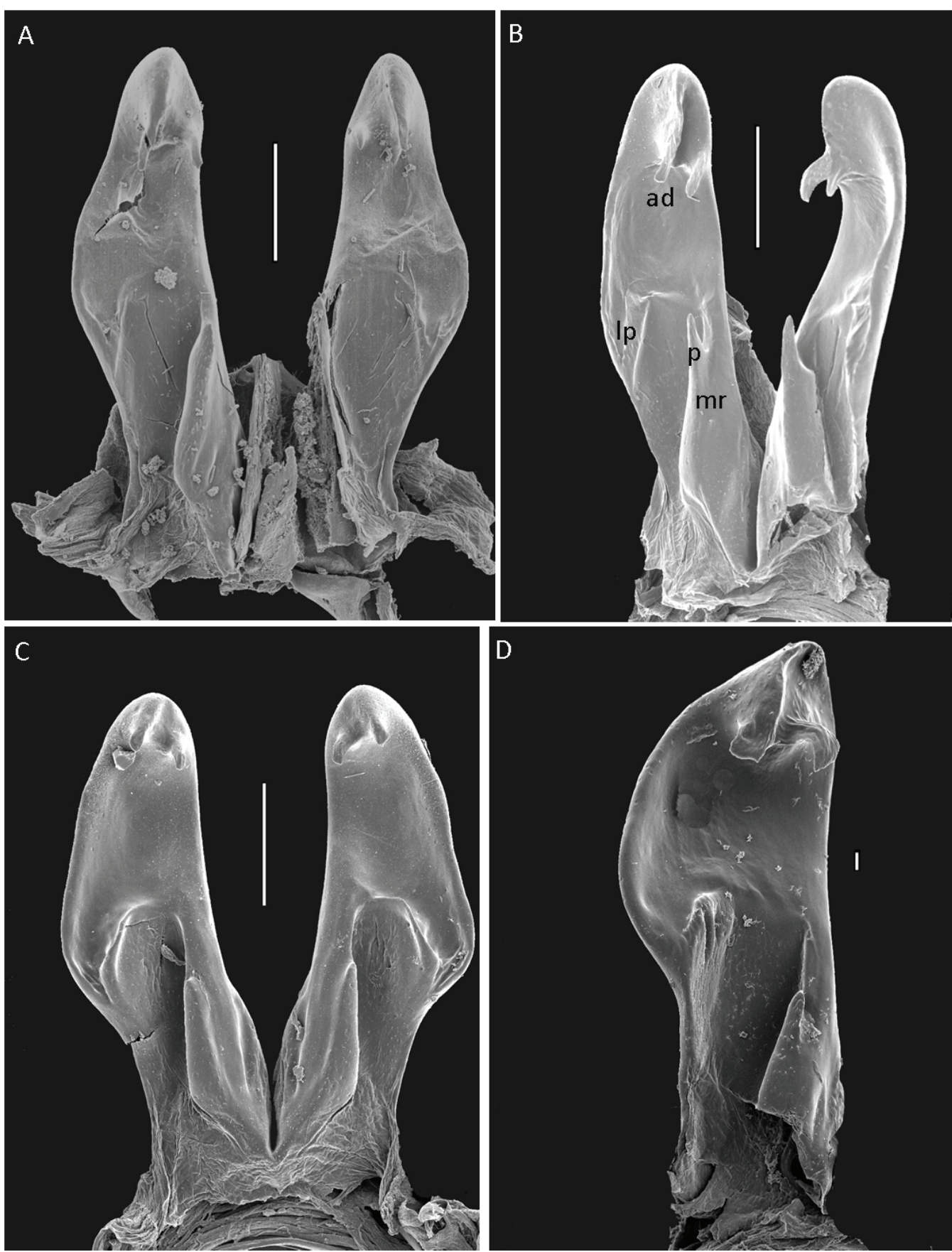

Fig. 3. Anterior gonopods, posterior views. A. D. typhlocanaria sp. nov., specimen from Barranco Draguillo. B. D. typhlocanaria sp. nov., specimen from Cueva de la Luna. C. D. oromii sp. nov. D. D. typhlops Ceuca, 1973, specimen from La Palma, right anterior gonopod. ad: apical denticles, lp: lateral prominence, $\mathrm{mr}$ : mesal ridge, p: projection. Scales $0.1 \mathrm{~mm}(\mathrm{~A}-\mathrm{C}), 0.01 \mathrm{~mm}(\mathrm{D})$. 


\section{Holotype}

§, El Sao (Agaete), UTM 28R 4354/31049 (2804’06”N, 15³9’27’W), MSS, 26 Dec. 2005, H. López leg. (DZUL).

\section{Paratypes}

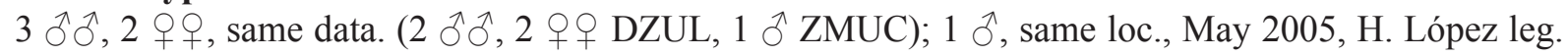

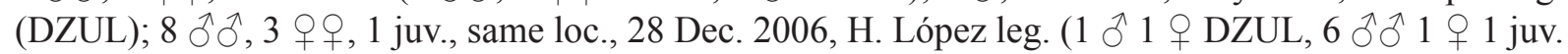
ZMUC, 1 ô 1 q MCNT); 2 우, same loc., 11 Aug. 2007, H. López leg. (DZUL), 5 $\widehat{\jmath}, 1$,, same loc.,

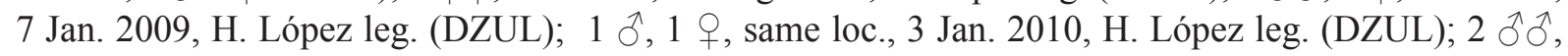
same loc., 4 Dec. 2010, H. López leg. (DZUL).

\section{Referred (non-type) material}

1 q, Caldera de los Marteles, UTM 28R 4481/30920 (2757’01'”N, 15³1'40”W), MSS, 19 Aug. 2006, H. López leg. (MCNT); 1 ㅇ, same loc., 7 Nov. 2008, H. López leg. (DZUL); $2 \hat{\jmath} \widehat{\partial}, 5$ 우, same loc., 27 Dec. 2008, H. López leg. (DZUL); 1 ㅇ, Los Majateles, UTM 28R 4505/30915 (2756’08”N, 15³0’10’W), MSS, 26 Dec. 2010, H. López leg. (DZUL).

\section{Total material}

$23 \overbrace{}^{\lambda}, 17$ 우, 1 juv. ( $1 \hat{\jmath}, 1$ analyzed).

\section{Description}

J: L 11-211/2 mm, H 0.82-1.00 mm, L/H 13-21, 31-53 podous rings + 1-4 apodous rings in front of telson. P: L 14-19 mm, H 0.95-1.08 mm, L/H 15-18, $42-47$ podous rings + 1-2 apodous rings in front of telson.

Colour. The preserved specimens are uniform whitish yellow. Defence glands in part visible by transparency as dark spots.
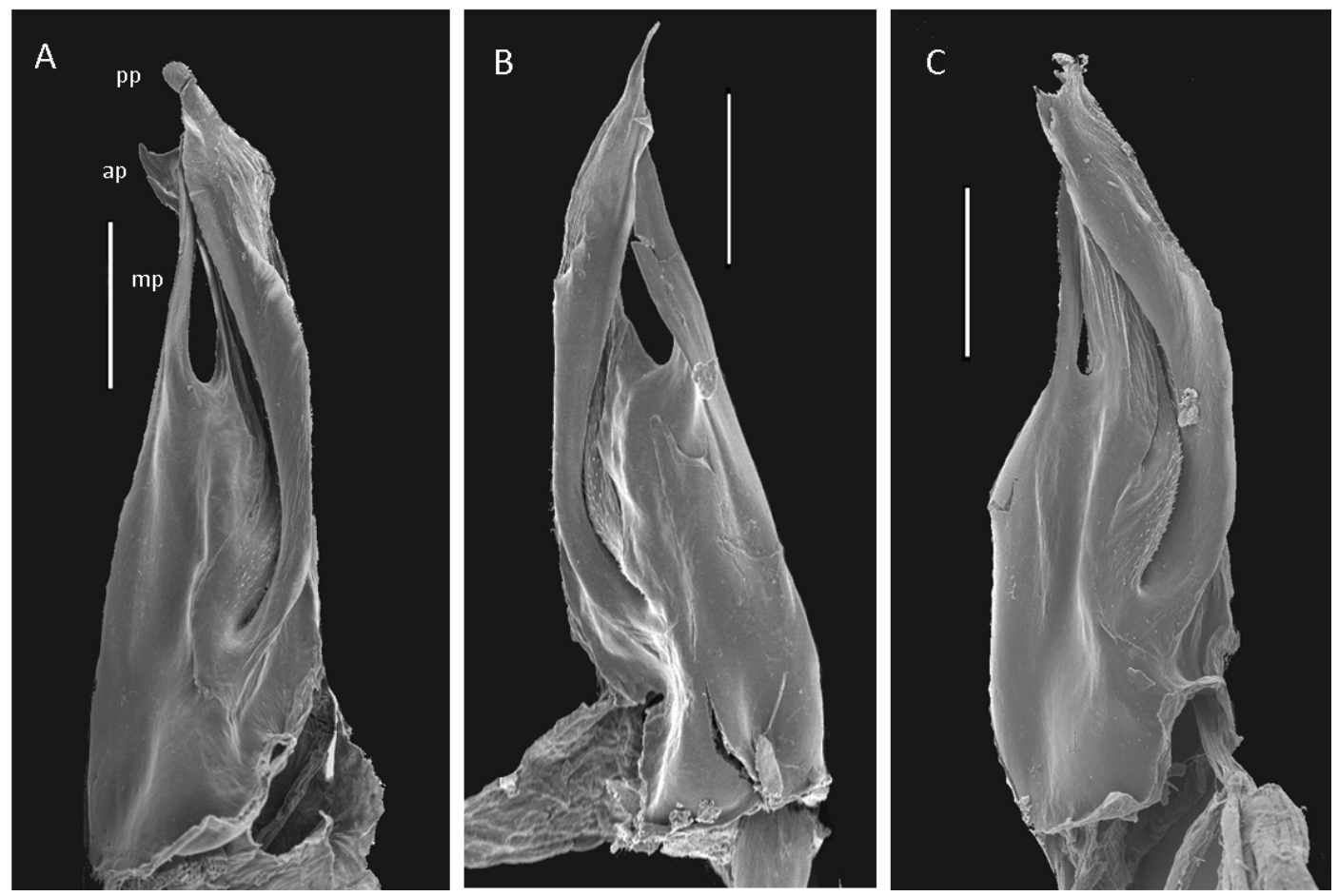

Fig. 4. Posterior gonopods, mesal views. A. D. typhlocanaria sp. nov., specimen from Barranco Draguillo. B. D. typhlocanaria sp. nov., specimen from Cueva de la Luna. C. D. oromii sp. nov. ap: anterior process, pp: posterior process, mp: mesomerital process. Scales $0.1 \mathrm{~mm}$. 
HeAd. No eyes. 4 supralabral setae. Setae on gnathochilarial stipes: 3 apical, 5 ( ( $)$ / 0 () nonapical. Length of antennae $162 \%$ of $\mathrm{H}$ in ${ }^{\lambda}, 123 \%$ of $\mathrm{H}$ in $\mathrm{q}$.

BoDY RINGS. Prozonites not furrowed. Metazonites unvaulted, with ca. 12 striae per dorsal quarter and a whorl of short setae on the posterior margin (Fig. 2B). Ozopore 1/4 - 1/3 metazonite length behind suture. Limbus cells length slightly more than $2 \times$ width; their free margin with a few tiny denticles (as in Enghoff 1992: figs 28-29).

LeGs. Length $84 \%$ of $\mathrm{H}$ in ${ }^{\lambda}, 74 \%$ of $\mathrm{H}$ in + . Claw: length $7-8 \%$ of leg, length/height $4.4-5.4$. Accessory claw $0.4-0.5 \times$ shorter than claw.

Preanal Ring. Without a projection, pilosity extensive.

\section{Male}

MANDiBULAR STIPITES. Without lobes.

LEgS. Second pair with ventral pads on postfemur and tibia. Postfemoral pads tiny, tibial pads small on midbody legs. Second pair with coxal pores.

Gonopods. (Figs 3C, 4C) As in D. typhlocanaria sp. nov., except for the lack of a terminal projection on the mesal ridge of the anterior gonopod.

\section{Female}

ReCEPTACUlum SEMINIS. A simple sack (as in Enghoff 1992: fig. 47).

\section{Distribution and habitat}

Endemic to Gran Canaria. Known only from the type locality in the NW part of the island, and from two further MSS sites in the East-Central part.

\section{Dolichoiulus longunguis sp. nov.}

Fig. 5

\section{Diagnosis}

Ablind species of Dolichoiulus. Differs from other blind Dolichoiulus species as shown in Table 1. Differs from the other blind Dolichoiulus on Gran Canaria in size (Figs 1, 5). Differs from D. typhlocanaria sp. nov. and $D$. oromii sp. nov. in having broader anterior gonopods, further from $D$. oromii sp. nov. in lacking metazonital setae and in having only marginal preanal pilosity, and further from $D$. typhlocanaria sp. nov. in lacking a terminal projection on the mesal ridge of the anterior gonopod. Differs from the widespread $D$. typhlops by being slenderer (Fig. 1, cf. Enghoff 2002: fig. 1).

\section{Etymology}

The name (noun in apposition) meaning "long claw" and refers to a distinguishing character of this species.

\section{Material studied}

\section{Holotype}

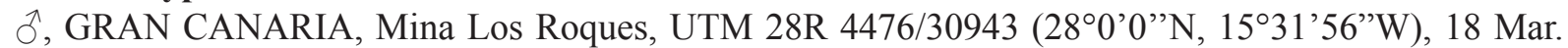
2012, M. Naranjo leg. (DZUL). 


\section{Paratype}

1 †, same loc., 23 Jan. 2012, M. Naranjo leg. (DZUL).

\section{Total material}

$1 \hat{\jmath}, 1$ q (analyzed).

\section{Description}

ภ: $\mathrm{L} 13 \mathrm{~mm}, \mathrm{H} 0.71 \mathrm{~mm}, \mathrm{~L} / \mathrm{H} 19,51$ podous rings +2 apodous rings in front of telson.

q: $\mathrm{L} 13 \mathrm{~mm}, \mathrm{H} 0.72 \mathrm{~mm}, \mathrm{~L} / \mathrm{H} \mathrm{18,} 49$ podous rings +1 apodous ring in front of telson.

CoLour. The preserved specimens are uniform pale brown.

HEAD. No eyes. 4 supralabral setae. Setae on gnathochilarial stipes: 3 apical, 4 ( $§) / 0$ (†) nonapical. Length of antennae $138 \%$ of $\mathrm{H}$ in $\mathrm{O}^{2}, 126 \%$ of $\mathrm{H}$ in 9 .

BoDY RINGS. Prozonites not furrowed. Metazonites unvaulted, striae quite indistinct dorsally (not studied with SEM). Ozopore c. 0.4 metazonite length behind suture. Limbus not studied (requires SEM).

Legs. Length $65 \%$ of $\mathrm{H}$ in ${ }^{\top}, 61 \%$ of $\mathrm{H}$ in $q$. Claw: length $11 \%$ of leg, length/height $4.5-5.4$. Accessory claw $0.3-0.4 \times$ shorter than claw.

PREANAL RING. Without a projection, pilosity marginal.

\section{Male}

MandibUlar stipites. Without lobes.

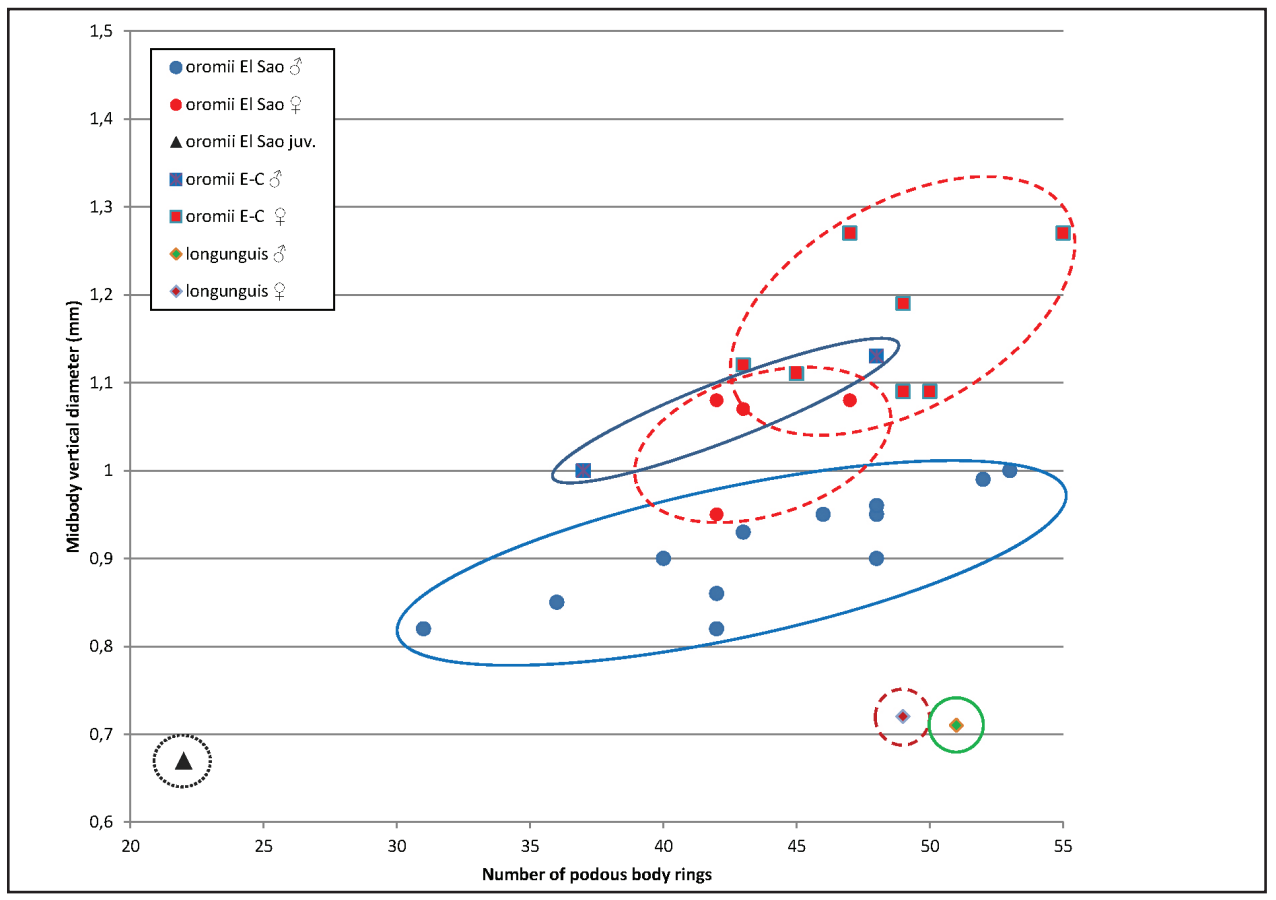

Fig. 5. Size diagram for Dolichoiulus oromii sp. nov. and D. longunguis sp. nov. The diagram shows number of podous (leg-bearing) body rings (p.r., x axis) and vertical body diameter in mm (y axis). For a given number of podous rings $D$. oromii sp. nov. is thicker than $D$. longunguis sp. nov. but thinner than D. typhlocanaria sp. nov. (see Fig. 1); specimens of D. oromii sp. nov. from East-Central Gran Canaria are thicker than those from the Northwest (El Sao), and females are thicker than males. 
Legs. Second pair with ventral pads on tibia only. Postfemoral pads absent, tibial pads tiny on midbody legs. Second pair with coxal pores.

ANTERIOR GONOPODS. Indistinguishable from the one shown in Fig. 3D, broader than in D. typhlocanaria sp. nov. and $D$. oromii sp. nov. Mesal ridge without a terminal projection. Lateral prominence distinct. Bowl broad, lateral margin regularly convex. Apical denticles distinct.

Posterior GONOPODS. Indistinguishable from those of D. typhlocanaria sp. nov. and D. oromii sp. nov.

\section{Female}

ReCEPTACulum SEMinis. A stalked sphere (as in Enghoff 1992: fig. 48).

\section{Distribution and habitat}

Endemic to Gran Canaria. Known only from the type locality in the east-central part of the island, Collected in an artificial gallery. The short legs and long claws in this species may suggest that it is a soil-digger species rather than a true cave species ( $c f$. Enghoff 1982). Among other Dolichoiulus species claws as long as those of $D$. longunguis sp. nov. are found only in D. blancatypa (Enghoff, 1992) comb. nov. from Tenerife, which also has short legs and is a soil-dweller (Enghoff 1992).

\section{Discussion}

It is perhaps not surprising that the first new Dolichoiulus species to be found after Enghoff (1992) are from the underground of Gran Canaria. Although caves are scarce on Gran Canaria, there are many deep artificial old galleries such as Mina de los Roques which have produced an interesting subterranean fauna (Naranjo et al. 2009). Also, the mesovoid (or mesocavernous) shallow stratum (MSS) is richly represented, and recent collecting activities here have revealed a rich endemic fauna of, e.g., Lagynochthonius Beier, 1951 pseudoscorpions, Symploce Hebard, 1916 cockroaches and Oromia Alonso-Zarazaga, 1987 weevils (Oromí et al. 2010; Mahnert, 2011). The abundant artificial caves and MSS spots not yet prospected suggest that the underground of Gran Canaria still has not been exhausted in terms of new millipede species.

\section{Acknowledgements}

Thanks to Pedro Oromí and Heriberto López (La Laguna) and to Manuel Naranjo (Las Palmas) for placing these specimens (and numerous other interesting Canarian millipedes) at my disposal, to GE Tebexcorade-La Palma and MELANSIS for collections during the project "Invertebrate fauna from the caves of Gran Canaria", and to Isabel Sanmartín, Madrid, for access to her unpublished phylogenetic analysis.

\section{References}

Attems C.G.1902. Myriopoden von Kreta, nebst Beiträgen zur allgemeinen Kenntnis einiger Gattungen. Sitzungsberichte der Akademie der Wissenschaften in Wien, mathematisch-naturwissenschaftliche Classe 111 (Abteilung 1): 527-614.

Enghoff H. 1982. The millipede genus Cylindroiulus on Madeira - an insular species swarm (Diplopoda, Julida: Julidae). Entomologica scandinavica Supplement 18: 1-142.

Enghoff H. 1992. Dolichoiulus - a mostly Macaronesian multitude of millipedes. With the description of a related new genus from Tenerife, Canary Islands (Diplopoda, Julida, Julidae). Entomologica scandinavica Supplement 40: 1-158.

Enghoff H. 2002. Dolichoiulus typhlops Ceuca, 1973, in Canarian caves (Diplopoda, Julida, Julidae). Vieraea 30: 147-152. 
Enghoff H. 2011. The millipede genera Cylindroiulus and Dolichoiulus as examples of Macaronesian species swarms. In: Serrano A.R.M., Borges P.A.V., Boieiro M. \& Oromí P. (eds) Terrestrial arthropods of Macaronesia - Biodiversity, ecology and evolution: 231-247. Sociedade Portuguesa de Entomologia, Lisboa.

Enghoff H. \& Báez M. 1993. Evolution and habitat patterns in endemic millipedes of the genus Dolichoiulus (Diplopoda: Julidae) on the Canary Islands. With notes on distribution patterns of other Canarian species swarms. Biological Journal of the Linnean Society 49: 277-301. http://dx.doi.org/ 10.1111/j.1095-8312.1993.tb00906.x

Fernández-Palacios J.M. 2011. The islands of Macaronesia. In: Serrano A.R.M., Borges P.A.V., Boieiro M. \& Oromí P. (eds) Terrestrial arthropods of Macaronesia - Biodiversity, ecology and evolution: 1-30. Sociedade Portuguesa de Entomologia, Lisboa.

López H. \& Oromí P. 2010. A pitfall trap for sampling the mesovoid shallow substratum (MSS) fauna. Speleobiology Notes 2: 7-11.

Mahnert V. 2011. A nature's treasury: Pseudoscorpion diversity of the Canary Islands, with the description of nine new species (Pseudoscorpiones, Chthoniidae, Cheiridiidae) and new records. Revista Ibérica de Aracnología 19: 27-45.

Naranjo M., Oromí P., Pérez A.J., González C., Fernández O., López H.D. \& Martín S. 2009. Fauna cavernícola de Gran Canaria. Secretos del mundo subterráneo. Sociedad Entomológica Canaria Melansis, Las Palmas de Gran Canaria.

Oromí P., López H. \& Mahnert V. 2010. Diversity and allopatric distribution in the Canarian MSS: a case study in an old island. In: Moškrič A. \& Trontelj P. (eds): Abstract book/20th International Conference on Subterranean Biology, Postojna, Slovenia, 29 August - 3 September 2010: 29. International Society for Subterranean Biology, Postojna.

Romero A. 2009. Cave Biology. Life in Darkness. Ecology, Biodiversity and Conservation Series, Cambridge University Press, Cambridge.

Verhoeff K.W. 1900. Beiträge zur Kenntnis paläarktischer Myriopoden. XVII. Aufsatz: Diplopoden aus dem Mittelmeergebiet. Archiv für Naturgeschichte 67, 1: 79-102.

Verhoeff K.W. 1910. Über Diplopoden. 11-15. Aufsatz (31.-35.). Beiträge zur Kenntnis der Glomeriden, Juliden, Ascospermophora und Lysiopetaliden, sowie zur Fauna Siziliens. Untersuchungen über Art- und Gruppensystematik, Morphologie, nachembryonale Entwicklung, Biologie und Geographie. Nova Acta. Abhandlungen der Kaiserlichen Leopoldinisch-Carolinischen Deutschen Akademie der Naturforscher 92 (2): 139-448.

Manuscript received: 28 March 2012

Manuscript accepted: 9 May 2012

Published on: 24 May 2012

Topic editor: Rudy Jocqué

In compliance with the $I C Z N$, printed versions of all papers are deposited in the libraries of the institutes that are members of the EJT consortium: Muséum National d'Histoire Naturelle, Paris, France; National Botanic Garden of Belgium, Meise, Belgium; Royal Museum for Central Africa, Tervuren, Belgium; Natural History Museum, London, United Kingdom; Royal Belgian Institute of Natural Sciences, Brussels, Belgium; Natural History Museum of Denmark, Copenhagen, Denmark. 